\title{
Comparing the usage of autologous blood transfusion with homologous blood transfusion in spine surgery
}

\author{
Hamdan, S. Dohar L. Tobing, Subroto Sapardan
}

\begin{abstract}
Abstrak
Transfusi darah autologous (TDA) adalah jenis transfusi darah paling aman baik untuk operator maupun pasien. Sedangkan teknik donasi pre operatif merupakan salah satu teknik TDA yang telah berhasil menurunkan permintaan darah homologous dengan sukses. Transfusi darah homologous (TDH) lebih banyak mempunyai risiko terjadinya komplikasi seperti penularan penyakit, reaksi anafilaktik, reaksi hemolitik dsb. Penelitian ini merupakan suatu uji paralel, membandingkan kelompok yang memperoleh TDA dengan kelompok yang memperoleh TDH pada operasi tulang belakang. Parameter yang digunakan adalah nilai hemoglobin(Hb) dan hematokrit(Ht) pre operasi (pasca donasi pada TDA), nilai Hb dan Ht pasca transfusi dan jumlah hari perawatan pasca operasi. Penelitian ini juga untuk mengetahui keberhasilan penggunaan TDA dilihat dari jumlah pasien yang akhirnya menggunakan TDH tambahan. Sampel adalah 74 pasien orthopaedi yang akan menjalani operasi tulang belakang dengan diagnosis fraktur, spondilitis TB, scoliosis, spinal stenosis dan spondilolisthesis. Pada kelompok TDA usia pasien 33,9 \pm 14 tahun, sedangkan pada TDH 29,1 \pm 11,5 tahun. Berat badan pemakai TDA 55,3 $\pm 11,1 \mathrm{~kg}$ dan pemakai TDH 52,8 \pm 9,7 kg. Jumlah donasi pre operatif pada pemakai TDA 798,6 $\pm 170 \mathrm{cc}$. Ada 12 pasien (32,4\%) yang jumlah donasi pre operatifnya tidak sesuai dengan permintaan. Pada kelompok pemakai TDA, ada delapan pasien (21,6\%) yang akhirnya memerlukan tambahan TDH rata-rata 550 cc. Ada tiga pasien (8,1\%) dari pemakai TDA mendapatkan transfusi yang tidak sesuai dengan indikasi (perdarahan < $15 \%$ dari total blood volume). Nilai Hb dan Ht pre operasi (pasca donasi) pada pemakai TDA secara bermakna $(p=0,001)$ lebih rendah daripada pemakai TDH. Nilai Hb pasca transfusi pada pemakai TDA secara tidak bermakna $(p=0,30)$ lebih rendah daripada pemakai TDH. Jumlah hari perawatan pasca operasi secara bermakna $(p=0,000)$ lebih tinggi pada pemakai TDH dibanding pemakai TDA. Dapat disimpulkan bahwa : ada 21,6\% dari pemakai TDA dengan teknik donasi pre operatif yang akhirnya memrlukan TDH tambahan; tidak ada perbedaan yang bermakna Hb, Ht pre operasi dan pasca transfusi pada pemakai TDA dan TDH; jumlah hari perawatan pasca operasi secara bermakna lebih tinggi pada pemakai TDH dibanding pemakai TDA. (Med J Indones 2004; 13: 17-23)
\end{abstract}

\begin{abstract}
Autologous Blood Transfusion (ABT) is the safest type of blood transfusion for the operator and the patient. The preoperative donation technique had already been reduced the homologous blood requirements successfully. Homologous Blood Transfusion (HBT) brings more risks in complications such as transmission of diseases, anaphylactic reactions, haemolitic reactions etc. This was a parallel study, comparing one group receiving ABT and a second group receiving HBT where in both groups were performed spine surgery. The parameter used was the hemoglobin $(\mathrm{Hb})$ and hematocrit $(\mathrm{Ht})$ content preoperatively (after donation of ABT) and after transfusion, total days in hospitalization after surgery. Another purpose of this study was also to achieve understandings in using ABT by considering the total patients who finally required additional HBT. There were 74 patients with diagnosis of spine fracture, tuberculous spondylitis, scoliosis, spinal stenosis and spondylolisthesis. In the ABT group the average age was 33,9 \pm 14 years old and the HBT group was 29,1 $\pm 11,5$ years old. Both groups consisted of 21 males and 16 females. Body weight of the ABT group was 55,3 $\pm 11,1 \mathrm{~kg}$ and the HBT group 52,8 $\pm 9,7 \mathrm{~kg}$. Amount of donations preoperatively in ABT was 798,6 $\pm 170 \mathrm{cc}$. There were 12 patients $(32,4 \%)$ where the donated blood amount preoperatively did not match up the requests. There were eight patients $(21,6 \%)$ in the ABT group that required additional HBT of about $550 \mathrm{cc}$. Three patients $(8,1 \%)$ of the ABT group received transfusion that did not match the indications (blood loss $<15 \%$ of the total blood volume). The Hb and Ht content preoperatively (after donation) of the ABT group significantly was less than the HBT group $(p=0,001)$. Hb content after transfusion in the ABT group was not significantly less than the $H B T$ group $(p=0,30)$. Hospitalization days after surgery were significantly higher in the HBT group $(p=0,000)$. In conclusions : there was 21,6\% of the ABT group with the preoperative donation technique that finally required additional HBT. Also there was no difference in the $\mathrm{Hb}$ and $\mathrm{Ht}$ content preoperatively and post transfusion in the ABT and HBT group, whereas hospitalization days after surgery were higher in the group receiving HBT than in the group receiving ABT. (Med J Indones 2004; 13: 17-23)
\end{abstract}

Keywords: autologous blood transfusion, homologous blood transfusion, spine surgery

Division of Orthopaedic and Traumatology, Department of

Surgery, Faculty of Medicine, Univesity of Indonesia /

Dr. Cipto Mangunkusumo Hospital, Jakarta, Indonesia 
It has been understood that the increase in blood transfusion is obvious from year to year without the increase of donors and therefore this decreases the supply of blood at The Blood Transfusion Service. In addition, postponement in surgery schedules is possible because of inadequate blood supply at The Blood Transfusion Service at a certain time, for example the Ramadhan month or when the patient's blood type is rare (negative Rhesus). It is also common that surgeons could not practice surgery at areas without The Blood Transfusion Service. Homologous blood transfusion (HBT) brings more risks in complications such as disease transmissions, anaphylactic / allergic reactions, haemolitic reactions etc. ${ }^{1-8}$

A recent study reported that HBT could cause immunologic suppression and causing higher infection rate and hospitalization days. ${ }^{9-15}$

In overcoming this burden, recently yet again, being developed an autologous blood transfusion (the patient himself donated blood for transfusion). With the use of autologous blood transfusion(ABT), advantages for the patient are elimination of transfusion reactions and diseases transmission (AIDS, hepatitis and syphilis), stimulates proliferation of eritropoesis with repeated phlebotomy, avoiding hemolytic or allergic reactions caused by alloantibody and the availability of blood for patients with rare blood types. Advantages for The Blood Transfusion Service are the availability of blood for patients with positive compatible reaction, an increase in homologous blood availability if autologous blood is not used and the decrease of homologous blood. ${ }^{13}$ Therefore it is recommended for orthopaedic surgeons and traumatologists to use $\mathrm{ABT}$ for patients where elective surgery are scheduled and blood transfusion after surgery are needed. ${ }^{16}$

There are three techniques for ABT, which are preoperative blood collection (differed autotransfusion), immediate pre operative phlebotomy (hemodilution autotransfusion/acute normovolemic hemodilution) and intra/post-operative blood collection. ${ }^{16,17}$

Among the $\mathrm{ABT}$ techniques the pre-operative blood collection technique (blood collected and stored preoperatively) is the simplest, easy and viable in use. This technique does not need sophisticated equipments and autologous blood may be obtained in large amounts as required. The disadvantages of this technique are the correct patients have to be selected for pre-operative donation; surgery schedule has to be punctuate and not permitted to be delayed nor before schedule because the total donation collected could be less than required, and if delayed the ABT could be expired; patients will feel more frequently of needle puncture pain for blood examination and donation; side effects in patients such as anemia pre-operatively because of frequent pre-operative blood donation; possibility of mistaken administration that causes risks of blood transfusion pitfalls (ABO incompatible). ${ }^{16,18}$

The aim of this study is to study prospectively the diversity among patients transfused by ABT (preoperative donation technique) and those transfused with HBT in spine surgery patients. The parameter used is the $\mathrm{Hb}$ and $\mathrm{Ht}$ content preoperatively (after donation of $\mathrm{ABT}), \mathrm{Hb}$ and $\mathrm{Ht}$ content after transfusion, hospitalization days after surgery. Another purpose of this study is also to understand the achievements in using $\mathrm{ABT}$ by considering the total patients who finally requires additional $\mathrm{HBT}$.

With this study, it suggests that orthopaedic surgeons and traumatologists could use ABT with the preoperative donation technique from the patients themselves in overcoming the need of blood. Without the requirements of additional blood transfusion from other individuals, this will reduce the use of HBT.

\section{METHODS}

Population of this study were orthopaedic patients at the Cipto Mangunkusumo National General Hospital and Fatmawati General Hospital from January 1999 to August 2001. The patients were selected from orthopaedic outpatients and in-patients and met the inclusion criteria. The inclusion criteria were patients where were performed spine surgery and the predicted blood loss during surgery was approximately $750-1500$ cc (blood loss $>15 \%$ of total blood volume) therefore blood donation were required 3-4 weeks before surgery; approval of phlebotomy with informed consent; adult age (> 15 years old); laboratory findings such as blood count, bleeding time, clotting time, renal function and liver function and blood glucose were within normal limits; cardiologic and lung diseases not found (from anamnesis, physical examination and additional examinations); body weight and physical condition were acceptable.

The patients then were divided into two groups with 37 patients for each group, where the first group received $\mathrm{ABT}$ and the second group received $\mathrm{HBT}$. 
The authors prepared the preoperative donation schedules for the ABT group according to the amount required and surgery schedule. One ferrum tablet twice everyday for a minimal of 2 weeks before donation were given for the ABT group. Donation / phlebotomy was performed for the ABT group by the authors, Blood Transfusion Service physician and their employee at the hospital for inpatients and at the Blood Transfusion Unit (BTU) of PMI DKI Jakarta for outpatients. Total blood taken was about $500-$ $1250 \mathrm{cc}$ depending on the requirements and condition of the patient. Each time blood obtained was about $250 \mathrm{cc}$ or $350 \mathrm{cc}$, therefore about 2-4 times were needed in a period of 2-4 weeks.

Everyday before phlebotomy the $\mathrm{Hb}$ content was examined and if $\mathrm{Hb}>11 \mathrm{~g} \%$, phlebotomy was performed but if $\mathrm{Hb} \leq 11 \mathrm{~g} \%$, the phlebotomy was postponed for a few days until $\mathrm{Hb}>11 \mathrm{~g} \%$.

At the Blood Transfusion Service (PMI), blood donation screening tests for HIV, Hepatitis B, Hepatitis $\mathrm{C}$ and Syphilis were performed.

If one of these screenings was positive, the patient then notified secretly and excluded from the study. Blood was then stored in a refrigerator with temperatures about 1$6^{\circ} \mathrm{C}$. Before that in the transfusion bag blood was mixed with preservatives or an anticoagulant substance of citrate phosphate dextrose adenine or CPDA-1 where blood could be preserved for 28 days.

For the ABT group, blood donated was then transfused during surgery or after surgery. Fourty eight hours after the last transfusion bag was given the $\mathrm{Hb}$ content was examined, if $\mathrm{Hb} \leq 10 \mathrm{~g} \%$ therefore additional HBT was required, but if $\mathrm{Hb}>10 \mathrm{~g} \%$ no additional HBT was required. In the HBT group the blood bank would provide HBT as required and would be transfused to the patient until $\mathrm{Hb}>10 \mathrm{~g} \%$.

Data consisting of age, sex, body weight, diagnosis, type of surgery, total amount of predictable blood loss, total donations preoperatively (for $\mathrm{ABT}$ ), $\mathrm{Hb}$ and $\mathrm{Ht}$ content preoperatively (after donation of $\mathrm{ABT}$ ), duration of surgery, blood loss during surgery, $\mathrm{Hb}$ and Ht content after transfusion, total patients who finally required additional HBT (for ABT patients), hospitalization days after surgery were submitted in a main table. Data analysis was by the SPSS (Statistical Package for Social Sciences) program.

\section{RESULTS}

Since January 1, 1999 until August 31, 2001 at the Cipto Mangunkusumo National General Hospital and Fatmawati General Hospital there were 74 patients with spine surgery and met the inclusion criteria (as sample size).

In Table 1, the characteristics of the ABT and HBT patients are recognized.

Both in ABT and HBT group there were 21 male patients patients and 16 female patients. In both groups there were 42 patients male $(56,8 \%)$ and 32 patients female $(43,2 \%)$.

Tabel 1. Characteristics of patients receiving ABT and HBT

\begin{tabular}{lccc}
\hline \multicolumn{1}{c}{ Variable } & $\begin{array}{c}\text { ABT } \\
\text { Average } \pm \text { SD }\end{array}$ & $\begin{array}{c}\text { HBT } \\
\text { Average } \pm \text { SD }\end{array}$ & p \\
\hline Age (year) & $33,9 \pm 14,4$ & $29,1 \pm 11,5$ & 0,169 (Mann-Whitney) \\
Body Weight (kg) & $55,3 \pm 11,1$ & $52,8 \pm 9,7$ & 0,359 (Mann-Whitney) \\
Total amount of predictable blood loss (cc) & $890,5 \pm 165,8$ & - & - \\
Total donations preoperatively (cc) & $798,6 \pm 170,9$ & - & - \\
Hb content preoperatively (after donation of ABT) (g\%) & $11,1 \pm 0,9$ & $12,9 \pm 1,4$ & 0,000 (Mann-Whitney) \\
Ht content preoperatively (vol\%) & $32,7 \pm 2,8$ & $37,8 \pm 4,0$ & 0,000 (Mann-Whitney) \\
Blood loss during surgery (cc) & $791,9 \pm 214,3$ & $1048,1 \pm 452,9$ & 0,007 (Mann-Whitney) \\
Percentage of blood loss during surgery (\%) & $19,1 \pm 6,1$ & $24,9 \pm 11,4$ & 0,009 (Mann-Whitney) \\
Duration of surgery (hours) & $3,7 \pm 0,7$ & $4,2 \pm 1,3$ & 0,104 (Mann-Whitney) \\
Total ABT and HBT (cc) & $798,6 \pm 170,9$ & $945,0 \pm 575,0$ & - \\
Hb content after transfusion (g\%) & $11,1 \pm 1,6$ & $11,4 \pm 0,9$ & 0,303 (Mann-Whitney) \\
Ht content after transfusion (vol \%) & $31,3 \pm 4,4$ & $33,2 \pm 3,1$ & 0,034 (Mann-Whitney) \\
Total additional HBT (for ABT patients) (cc) & $543,7 \pm 90,4$ & - & - \\
Hospitalization days after surgery (days) & $11,7 \pm 2,7$ & $18,9 \pm 5,2$ & 0,000 (Mann-Whitney) \\
\hline
\end{tabular}


In ABT group, the majority of cases were spine fracture of 16 patients $(43,2 \%)$ and there was only one case of spondilolysthesis $(2,7 \%)$. In HBT group the majority of cases were tuberculous spondilitis of 18 patients $(48,6 \%)$ and one case of spondilolysthesis $(2,7 \%)$, as seen in Table 2 .

Tabel 2. Diagnosis distribution of ABT and HBT groups

\begin{tabular}{lccc}
\hline \multicolumn{1}{c}{ Diagnosis } & $\begin{array}{c}\text { ABT } \\
\text { (patient(s)) }\end{array}$ & $\begin{array}{c}\text { HBT } \\
\text { (patient(s)) }\end{array}$ & $\begin{array}{c}\text { Total } \\
\text { Amount }\end{array}$ \\
\hline $\begin{array}{l}\text { Tuberculous } \\
\text { spondilytis }\end{array}$ & 13 & 18 & 31 \\
Spine fracture & 16 & 13 & 29 \\
Scoliosis & 2 & 3 & 5 \\
Spinal stenosis & 5 & 2 & 7 \\
Spondilolysthesis & 1 & 1 & 2 \\
\hline Total & 37 & 37 & 74 \\
\hline
\end{tabular}

For ABT group, the majority of surgical procedures were open reduction and stabilization with the PSSW (Pedicle Screw Sublaminar Wire) system for 16 cases of spine fractures $(43,2 \%)$ and there was only one surgical procedure of PSSW removal $(2,7 \%)$. Whereas in HBT group, majority surgical procedures were debridement, decompression, correction and stabilization with the PSSW (Pedicle Screw Sublaminar Wire) system in 18 patients $(48,6 \%)$ with tuberculous spondylitis and there was only one surgical procedure of PSSW removal $(2,7 \%)$. This is noted in Table 3.

Tabel 3. Surgical Procedures for ABT and HBT groups

\begin{tabular}{lcccc}
\hline No. & $\begin{array}{c}\text { Surgery } \\
\text { Procedure }\end{array}$ & $\begin{array}{c}\text { ABT } \\
\text { (patient(s)) }\end{array}$ & $\begin{array}{c}\text { HBT } \\
\text { (patient(s)) }\end{array}$ & $\begin{array}{c}\text { Total } \\
\text { Amount }\end{array}$ \\
\hline 1. & 1 & 12 & 18 & 30 \\
2. & 2 & 16 & 13 & 29 \\
3. & 3 & 2 & 3 & 5 \\
4. & 4 & 6 & 3 & 9 \\
5. & 5 & 1 & 1 & 2 \\
\hline & Total & 37 & 37 & 74 \\
\hline
\end{tabular}

Note:

1 = debridement, decompression, correction and PSSW stabilization

2 = reposition and stabilization with the PSSW

3 = correction, instrumentation of Harrington rod + reconstruction plate

$4=$ decompression, PSSW/PSP stabilization

5 = PSSW removal
In the ABT group, the total pre operative donation average was 798,6 cc with a standard deviation of $170,9 \mathrm{cc}$. The largest donation was $1200 \mathrm{cc}$ which was in one patient $(2,7 \%)$, and the smallest donation was $500 \mathrm{cc}$, which was in six patients $(16,2 \%)$. Donation mostly made was $750 \mathrm{cc}$, that was in 17 patients (46\%).

The $\mathrm{Hb}$ content preoperatively (in ABT group after donation) is showed in Table 4. In ABT group the lowest $\mathrm{Hb}$ content preoperatively was $10,0 \mathrm{~g} \%$ and the majority $\mathrm{Hb}$ content were $10-11 \mathrm{~g} \%$ in 19 patients $(51,3 \%)$. In HBT group the lowest $\mathrm{Hb}$ content preoperatively was $10,2 \mathrm{~g} \%$ and the majority $\mathrm{Hb}$ of content were $12-13 \mathrm{~g} \%$ in 14 patients $(37,8 \%)$. While noticing $\mathrm{Hb}$ content preoperatively with the MannWhitney test, a significant difference was found between the two groups $(p=0,000 ; p<0,05)$.

Table 4. Preoperative Hb content in ABT and HBT groups

\begin{tabular}{cccc}
\hline $\begin{array}{c}\text { Hb content } \\
(\text { gr\%) }\end{array}$ & $\begin{array}{c}\text { ABT } \\
\text { (patient(s)) }\end{array}$ & $\begin{array}{c}\text { HBT } \\
\text { (patient(s)) }\end{array}$ & Total \\
\hline $10-11$ & 19 & 2 & 21 \\
$11-12$ & 11 & 7 & 18 \\
$12-13$ & 4 & 14 & 18 \\
$13-14$ & 2 & 8 & 10 \\
$14-15$ & 1 & 4 & 5 \\
$>15$ & - & 2 & 2 \\
\hline Total & 37 & 37 & 74 \\
\hline
\end{tabular}

The Ht content preoperatively is showed in table 5. In ABT group the lowest $\mathrm{Ht}$ content preoperatively was 30,0 vol\%, the majority of $\mathrm{Ht}$ content were $30-32$ vol\% in 18 patients $(48,6 \%)$. In HBT group the lowest Ht content preoperatively was 30,0 vol\% and the majority of Ht content were 34-36 vol\% in 11 patients $(29,7 \%)$. While noticing $\mathrm{Ht}$ content preoperatively with the Mann-Whitney test, a significant difference was found between the two groups $(p=0,000 ; p<0,05)$.

Table 5. Preoperative Ht content in ABT and HBT groups

\begin{tabular}{cccc}
\hline $\begin{array}{c}\text { Ht content } \\
(\text { vol\%) }\end{array}$ & $\begin{array}{c}\text { ABT } \\
(\text { patient(s)) }\end{array}$ & $\begin{array}{c}\text { HBT } \\
\text { (patient(s)) }\end{array}$ & Total \\
\hline $28-30$ & 2 & 2 & 4 \\
$30-32$ & 18 & - & 18 \\
$32-34$ & 6 & 2 & 8 \\
$34-36$ & 5 & 11 & 16 \\
$36-38$ & 3 & 8 & 11 \\
$38-40$ & 2 & 5 & 7 \\
$40-42$ & 1 & 6 & 7 \\
$>42$ & - & 3 & 3 \\
\hline Total & 37 & 37 & 74 \\
\hline
\end{tabular}


Table 6 shows $\mathrm{Hb}$ content after transfusion. In ABT group the lowest $\mathrm{Hb}$ content after transfusion was 7,8 $\mathrm{g} \%$ and the highest was $16,6 \mathrm{~g} \%$ and the majority were $11-12 \mathrm{~g} \%$, which were in 11 patients $(29,7 \%)$. In HBT group the lowest $\mathrm{Hb}$ content after transfusion was $9,9 \mathrm{~g} \%$ and the highest was $13,3 \mathrm{~g} \%$ and the majority were $10-11 \mathrm{~g} \%$ and $11-12 \mathrm{~g} \%$, which were in 12 patients $(32,4 \%)$ each. While noticing $\mathrm{Hb}$ content after transfusion with the Mann-Whitney test, no significant difference was found between the two groups $(\mathrm{p}=0,303 ; \mathrm{p}>0,05)$.

Table 6. Hb content after transfusion in ABT and HBT groups

\begin{tabular}{cccc}
\hline $\begin{array}{c}\text { Hb content } \\
(\mathbf{g r} \%)\end{array}$ & $\begin{array}{c}\text { ABT } \\
(\text { patient(s) })\end{array}$ & $\begin{array}{c}\text { HBT } \\
\text { (patient(s)) }\end{array}$ & Total \\
\hline$\leq 9$ & 3 & - & 3 \\
$9-10$ & 5 & 2 & 7 \\
$10-11$ & 9 & 12 & 21 \\
$11-12$ & 11 & 12 & 23 \\
$12-13$ & 7 & 9 & 16 \\
$13-14$ & 1 & 2 & 3 \\
$>14$ & 1 & - & 1 \\
\hline Total & 37 & 37 & 74 \\
\hline
\end{tabular}

Table 7 shows Ht content after transfusion. In ABT group the lowest hematocrit number after transfusion was $21,7 \mathrm{vol} \%$ and the highest was $46,0 \mathrm{vol} \%$ and the majority were $30-32$ vol\%, which were in 12 patients $(32,4 \%)$. In HBT group the lowest hematocrit number after transfusion was 28,0 vol\% and the highest was $39,0 \mathrm{vol} \%$ and the majority were $30-32 \mathrm{vol} \%$, which were in 12 patients $(32,4 \%)$. While noticing $\mathrm{Ht}$ content after transfusion with the Mann-Whitney test, a significant difference was found between the two groups $(\mathrm{p}=0,034 ; \mathrm{p}<0,05)$.

Table 7. Ht content after transfusion in ABT and HBT groups

\begin{tabular}{cccc}
\hline $\begin{array}{c}\text { Ht content } \\
(\text { vol\%) }\end{array}$ & $\begin{array}{c}\text { ABT } \\
\text { (patient(s)) }\end{array}$ & $\begin{array}{c}\text { HBT } \\
\text { (patient(s)) }\end{array}$ & Total \\
\hline$\leq 26$ & 3 & - & 3 \\
$26-28$ & 6 & 2 & 8 \\
$28-30$ & 2 & 2 & 4 \\
$30-32$ & 12 & 12 & 24 \\
$32-34$ & 6 & 10 & 16 \\
$34-36$ & 6 & 2 & 8 \\
$36-38$ & 1 & 7 & 8 \\
$>38$ & 1 & 2 & 3 \\
\hline Total & 37 & 37 & 74 \\
\hline
\end{tabular}

In $\mathrm{ABT}$ group, after the whole $\mathrm{ABT}$ were transfused and still required additional HBT were 8 patients $(21,6 \%)$. The highest additional HBT was $750 \mathrm{cc}$, which was in 1 patient $(12,5 \%)$ in a surgical procedure of debridement, decompression, correction and stabilization of PSSW system for tuberculous spondilitis vertebrae thoracal 9-12. The lowest additional HBT and most often were $500 \mathrm{cc}$ for 6 patients (75\%).

In $\mathrm{ABT}$ group the shortest hospitalization days after surgery was 6 days in 1 patient $(2,7 \%)$ and the longest hospitalization days after surgery was 20 days in 1 patient $(2,7 \%)$ and the majority of hospitalization days after surgery were 7-10 days, which were in 15 patients $(40,5 \%)$. In HBT group the shortest hospitalization days after surgery was 7 days in 1 patient $(2,7 \%)$ and the longest hospitalization days after surgery was 24 days in 1 patient $(2,7 \%)$ and the majority of hospitalization days after surgery were 1316 days and 16-19 days, which were both in 9 patients $(24,3 \%)$ each. While noticing hospitalization days after surgery with the Mann-Whitney test, a significant difference was found between the two groups $(\mathrm{p}=0,000 ; \mathrm{p}<0,05)$.

A positive correlation $(\mathrm{r}=0,114)$ but not significant $(p=0,502)$ between the total preoperative donation with hospitalization days after surgery in ABT group is showed at table 8 .

Table 8. Correlation between the total amount of preoperative donation with blood loss during surgery and hosptalization days after surgery in ABT group.

\begin{tabular}{lll}
\hline \multicolumn{1}{c}{ Variable } & \multicolumn{2}{c}{$\begin{array}{c}\text { Total donations } \\
\text { preoperatively }\end{array}$} \\
\hline Blood loss during surgery & $\mathrm{r}=0,477$ & $\mathrm{p}=0,003$ \\
Hospitalization days after surgery & $\mathrm{r}=0,114$ & $\mathrm{p}=0,502$ \\
\hline
\end{tabular}

\section{DISCUSSION}

Actually more samples could be applied to this research such as children and patients with cardiovascular disorder, because previous studies have already discovered that ABT with the preoperative donation technique could be done in children and patients with cardiovascular disorder, so there have no contraindications. ${ }^{16,18}$ 
Seven patients were excluded from this study, 4 patients because failing in donation 2-3 times after being scheduled due to insufficient of $\mathrm{Hb}$ content. One patient because The Blood Transfusion Service (PMI) employee did not arrive twice to perform phlebotomy, 2 patients because the surgery schedule was earlier and the blood donation was only once. Therefore, cooperation between the patient, physician and Blood Transfusion Service is necessary, thus incidents as these are avoidable.

Spine fracture was the majority diagnosis found in ABT group. In HBT group the majority diagnosis was tuberculous spondylitis since majority of this patients had poor main appearance and nutrition status, therefore could not perform preoperative donation. At the Cipto Mangunkusumo National General Hospital the ABT was performed in spine surgery since this surgery was the most often in needing of blood transfusion. The ABT with the preoperative donation technique supposedly not only performed in spine surgery only but also in other orthopaedic cases as in the hip area, shoulder area and multiple fracture. Other studies showed that the ABT with preoperative donation technique was done in total hip replacement and total knee replacement. ${ }^{8,13,15}$

One study reported that there were $11 \%$ of the patients receiving $\mathrm{ABT}$, which were not indicated for transfusion or the blood loss during surgery was $<15 \%$ from the total blood volume. ${ }^{16}$ The ABT group in this study with blood loss during surgery was $<15 \%$ from the total blood volume were 3 patients $(8,1 \%)$ or less than in other studies, consequently according to the theory these 3 patients should not be transfused even with their own blood. Although ABT was a safe procedure, but risks and human error were possible as in providing the wrong blood bag. ${ }^{16}$ The surgeons should always perform standard indications for transfusion in administering ABT.

Total average of preoperative donations in ABT group was $798,6 \mathrm{cc}$ or about 3,2 units. This did not differ with previous studies whereas the average ABT preoperative donations are 2-3 units. ${ }^{16}$ Total average of preoperative donations in $\mathrm{ABT}$ group was almost the same with ABT + additional HBT group, which was $750-800 \mathrm{cc}$ ( 3 units). The average HBT required was $500 \mathrm{cc}$ or 2 units. In this study there were 12 patients $(32,4 \%)$ with total donations preoperatively not as required or being short of $250-500 \mathrm{cc}$ from the amount required. This number was higher than in previous studies, which were $24 \% .^{16}$ The causes of this condition included there were seven patients $(58,3 \%)$ with earlier surgery than scheduled, therefore blood collected was not enough. In the other hand, there were two patients $(16,7 \%)$, where donations were enough but the surgery schedule postponed because of VIP patients needed earlier surgery. Therefore 1-2 units of blood becoming expired and could not be used. Three patients $(25 \%)$ because the $\mathrm{Hb}$ content when donation performed was inadequate $(<11 \mathrm{gr} \%)$, therefore donation was postponed and the total donation was not enough as required. Previous study notified that the causes of inadequate donation than required were a low $\mathrm{Hb}$ content therefore donation was postponed, side effects which occured like headaches and unconsciousness thus donation was stopped. Another cause was the hesitation of the patient in phlebotomy. ${ }^{16}$

Most of ABT group patients requiring additional HBT were patients with less preoperative donation than planned (average of $250-500 \mathrm{cc}$ ). There were five patients $(13,5 \%)$ of 12 patients $(32,4 \%)$ in ABT group, where their preoperative donation were not enough a required. This is similar with a previous study by Howard et al. (1992) in New Castle, whereas concluded that patients underwent preoperative donation with a smaller amount eventually required additional HBT more than the amount donated. ${ }^{13}$

In $\mathrm{ABT}$ group, the $\mathrm{Hb}$ and $\mathrm{Ht}$ contents preoperatively (after donation) were significantly lower than in HBT group, but after the last donation the average $\mathrm{Hb}$ content was $11,1 \mathrm{gr} \%$ and the average Ht content was 32,7 vol\% and still tolerated to perform surgery. Of course, patients with preoperative donations when scheduled to surgery were in maximal eritropoesis. $\mathrm{The} \mathrm{Hb}$ content after transfusion in ABT group was not significantly different with HBT group; therefore, it was better for ABT group because the possibility in additional HBT was decreased.

In ABT group, from the 37 patients performing preoperative donations of $800 \mathrm{cc}$ in average, there were eight patients $(21,6 \%)$ where eventually in need of additional HBT of $500 \mathrm{cc}$ in average. This percentage $(21,6 \%)$ was less than written in previous studies, which stated that in $\mathrm{ABT}$ group that required additional HBT was $56,3 \% .^{13}$ The best criteria of the ABT program is totally avoiding the use of additional HBT.

According to a study by Triulzi et al. (1992) the difference in the hospitalization days after surgery in 
ABT and HBT groups was 2,7 days. ${ }^{14,15}$ In this study the difference in the hospitalization days after surgery in ABT and HBT groups was 7,6 days (more significant). The fewer total days of hospitalization after surgery will become a tendency of higher use in ABT because the risk of nosokomial infection could be avoided and all costs reduced. In this study other organs infected were not searched for after surgery. Observations should be made to know if infection has occurred in the surgery wound or outside the surgery wound and requiring antibiotic therapy. Previous study stated that every patient receiving HBT until $32 \%$ was apparent to get infection, this was significantly higher than in $\mathrm{ABT}$ patients, that were only $3 \%$. Other potential risk factors in becoming infected as in duration of surgery, elderly patients, amount of blood loss, anesthesia type, operator, leucocytopenia, anemia and additional diagnosed diseases does not cause difference in becoming infected in patients receiving HBT. The main cause of higher risks of infection is the immunology changes in the recipient. ${ }^{15}$

\section{CONCLUSION}

The $\mathrm{Hb}$ and $\mathrm{Ht}$ contents preoperatively (post transfusion) in ABT group were significantly $(p=0,000)$ lower than HBT group. As for the average $\mathrm{Hb}$ and $\mathrm{Ht}$ content preoperatively in $\mathrm{ABT}$ group were in normal limits, which were $11,1 \mathrm{~g} \%$ \& 32,7 vol\%. $\mathrm{The} \mathrm{Hb}$ content post transfusion in ABT group was not significantly $(\mathrm{p}=0,30)$ lower than HBT group, but this decreased could be unnoticed.

In ABT group there was 21,6\%, which eventually required additional $\mathrm{HBT}$ with an average of $550 \mathrm{cc}$, therefore the ABT program outcome with the preoperative donation technique was still far from satisfying. Total days in hospitalization after surgery $(\mathrm{p}=0,000)$ was significantly longer in HBT group than in ABT group. The use of ABT for patients performing elective orthopaedic surgery is an approach in reducing morbidity because of infection after surgery.

\section{REFERENCES}

1. Majkowski RS, Newman JH, Currie IC. Postoperative collection and reinfusion of autolog blood in total knee arthroplasty. Annals of the Royal College of Surgeons of England 1991; 73: 381-4.

2. DeBois WJ, Garcia N, Krieger KH, Rosengart TK, Helm RE, Isow W. Open Heart operations without transfusion using a multimodality blood conservation strategy in 50 Jehovah's witness patients : implications for "bloodless" surgical technique. J Am Coll Surg 1997; 184: 618-29

3. Connor JP, Morris PC, Alagoz T, Anderson B, Bottles K, Buller RE. Intraoperative autolog blood collection and auto transfusion in the surgical management of early cancers of the uterine cervix. Obstet Gynecol 1995; 86(3): 373-8

4. Slagis SV, Benjamin JB, Volz RG, Giordano GF. Postoperative blood salvage in total hip and knee arthroplasty: a randomized controlled trial. J Bone Joint Surg (Br) 1991; 73-B (4):591-4

5. Clements DH, Sculco TP, Burke SW, Mayer K, Levine DB. Salvage and reinfusion of postoperative sanguineous wound drainage. J Bone Joint Surg 1992; 74-A (5):64650 .

6. Lubin J, Greenburg JJ, Yahr WZ, Haynes JL, Paul E. The use of autolog blood in open heart surgery. Transfusion 1974; 14(6): 602-7.

7. Kristensen PW, Sorensen LS, Thyregod HC. Auto transfusion of drainage blood in arthroplasty: a prospective, controlled study of 31 operations. Acta Orthop Scand 1992; 63(4):377-80.

8. Faris PM, Ritter MA,, Keating EM, Valeri CR. Unwashed filtered shed blood collected after hip and knee arthroplasties: a source of autolog red blood cells. J Bone Joint Surg 1991; 73-A(8): 1169-77.

9. Biesma DH, Marx JJM, De Wiel AV. Collection of autolog blood before elective hip replacement: a comparison of the results with the collection of two and four units. J Bone Joint Surg 1994; 76-A (10) :1471-5.

10. Fernandez MC, Gottlieb M, Menitove JE. Blood transfusion and postoperative infection in orthopaedic patients. Transfusion 1992; 32(4): 318-22.

11. Nash PA, Schrepferman CG, Rowland RG, et al. The impact of pre-donated autolog blood and intraoperative isovolemic haemodilution on the outcome of transfusion. Br J Urol 1996; 77: 856-60.

12. Rosenberg PH. Auto transfusion: a complement to conventional transfusion. Acta Orthop Scand 1992; 63(4):367-8.

13. Howard HL, Rushambuza FG, Martlew VJ, Satchi G, Maggs BB. Clinical benefits of autolog blood transfusion: an objective assessment. Clin Lab Haemat 1993; 15:16571.

14. Triulzi DJ, Vanek K, Ryan DH, Blumberg N. A clinical and immunologic study of blood transfusion and postoperative bacterial infection in spinal surgery. Transfusion 1992; 32(6): 517-23.

15. Murphy P, Heal JM, Blumberg N. Infection or suspected infection after hip replacement surgery with autolog or homolog blood transfusions. Transfusion 1991; 31(3): 212-17.

16. Simpson MB, Orsini E, Eilert RE. Autolog transfusion for orthopaedic procedures at a children's hospital. J Bone Joint Surg 1992; 74-A (5) : 562-7.

17. Brica SM, Pineda AA, Taswel HF. Autolog blood transfusion. Mayo Clin Proc 1976; 51: 723-34.

18. Tyler VV. Autolog blood donation and transfusion. In: Tyler VV, ed. Technical manual. American Association of Blood Banks. 13 ${ }^{\text {th }}$ ed. Maryland: American Association of Blood Banks, 1999; 111-25. 
